\title{
Pemahaman Siswa Terhadap Materi Perkembangan Masyarakat Masa Reformasi Sub-bab Konflik Sambas 1999
}

\author{
EMI TIPUK LESTARI \\ STKIP PGRI Pontianak \\ tipoeklestari@gmail.com
}

\begin{abstract}
Abstrak
Penelitian ini bertujuan mengetahui pembelajaran materi perkembangan masyarakat Indonesia pada masa reformasi sub-bab konflik antaretnis sambas tahun 1999 sebagai sumber belajar sejarah kelas XII IPS SMAN 8 Pontianak, meliputi: (1) Pelaksanaan guru dalam menjelaskan materi, (2) Strategi guru dalam menyampaikan nilai historis pada materi, (3) Pemahaman siswa terhadap materi. Penelitian ini menggunakan metode deskriptif. Sampel diambil dengan teknik purposif sampling. Data dikumpulkan dengan observasi langsung, komunikasi langsung, dan dokumentasi. Analisis yang digunakan adalah deskriptif kualitatif. Hasil penelitian menunjukkan: (1) pelaksanaan guru dalam menyampaikan materi menggunakan ceramah bervariasi diselingi tanya jawab, dan menampilkan power point diselingi film dokumenter. (2) Strategi guru yaitu dengan mengarahkan siswa menyaksikan film kemudian menjelaskan dampak buruk dari peristiwa tersebut dan mengajak siswa mengambil hikmahnya. (3) Pemahaman siswa terhadap materi cukup baik, yang ditunjukkan keterlibatan siswa secara aktif dalam pembelajaran. Materi ini menjadikan siswa berfikir kronologis dan memiliki pengetahuan peristiwa masa lampau agar siap menghadapi masa depan.

Kata Kunci : pemahaman materi, konflik antaretnis
\end{abstract}

\begin{abstract}
This research aims to know the teaching of the Indonesian society development during the reformation era of Sambas interethnic conflict 1999 sub-chapter as a source of history learning of grade XII Social Studies subjects at SMAN 8 Pontianak. It includes (1) learning materials explanation, (2) The strategy of teachers in conveying historical values on materials,(3) Students' understanding of the materials. This research employs descriptive method. The samples were taken by utilizing purposive sampling techniques. The data were collected through direct observations, direct communications, and documentations. The analysis performed in this research is qualitative descriptive analysis. The findings show that: (1) the teachers use varied methods in presenting the materials such as using question and answer, displaying power points and playing documentary films. (2) The teacher's strategy is directing the students to watch the film, then they explain the effects of such events presented in the film and invite students to take a lesson from the film. (3) The students' understanding on the material is quite well, which indicated by the active involvement of students in learning. This material makes the students think chronologically and have knowledge of the events of the past to prepare for the future.
\end{abstract}

Keywords: materials understanding, interethnic conflicts 


\section{PENDAHULUAN}

Pembelajaran merupakan jantung dari proses pendidikan dalam suatu instuisi pendidikan. Kualitas pembelajaran bersifat kompleks dan dinamis, dapat dipandang dari berbagai persepsi dan sudut pandang melintas garis waktu. Pada tingkat mikro, pencapaian kualitas pembelajaran merupakan tanggung jawab profesional seorang guru, misalnya melalui penciptaan pengalaman belajar yang bermakna bagi siswa dan fasilitas yang didapat siswa untuk mencapai hasil belajar yang maksimal. Pada tingkat makro, melalui sistem pembelajaran yang berkualitas, lembaga pendidikan bertanggung jawab terhadap pembentukkan tenaga pengajar yang berkualitas, yaitu yang dapat berkonstribusi terhadap perkembangan intelektual, sikap, dan moral dari setiap individu peserta didik sebagai anggota masyarakat. Adapun faktorfaktor yang berpengaruh terhadap proses perkembangan adalah pembelajaran, baik secara eksternal maupun internal.

Dalam konteks kehidupan berbangsa dan bernegara, pembelajaran sejarah sebenarnya memiliki posisi yang sangat strategis mencakup hakikat dan maknanya. Pembelajaran sejarah adalah suatu proses untuk membantu mengembangkan potensi dan kepribadian melalui pesan-pesan sejarah agar menjadi warga bangsa yang arif dan bermartabat. Sejarah dalam hal ini merupakan totalitas dari aktivitas manusia di masa lampau dan sifatnya dinamis yaitu masa lampau itu bukan suatu final, tetapi bersifat terbuka dan terus berkesinambungan dengan masa kini dan yang akan datang. Karena itu sejarah dapat diartikan merupakan sebuah ilmu yang mengkaji mengenai perkembangan kehidupan manusia meliputi peradaban, komunikasi dan segala aspek kejadiannya, untuk kemudian dapat memberikan penilaian sebagai pedoman penentuan keadaan sekarang, serta cerminan untuk masa yang akan datang.

Sebagai suatu disiplin ilmu yang juga diajarkan dari tingkat pendidikan sekolah dasar hingga sekolah tingkat atas pembelajaran sejarah juga tidak luput dari permasalahan yang terletak pada beberapa macam hal, se- bagai suatu ilmu yang lebih menitik beratkan kepada peristiwa, kisah dan sebagain yang bersifat historis. Pembelajaran sejarah di sekolah selama ini kurang menarik, bahkan sering dianggap membosankan dan dirasakan hanya sebagai rangkaian fakta-fakta yang berupa urutan tahun, tokoh dan peristiwa belaka yang jauh dari lingkungan sosial peserta didik, terutama di luar pulau jawa, karena selama ini materi kurikulum didominasi peristiwa sejarah di Pulau Jawa (Jawa sentris).

Lemahnya strategi atau pola pembelajaran sejarah di Indonesia juga menjadi faktor penting penghambat minat siswa dalam mempelajari sejarah. Pendidikan yang ada masih mengharuskan siswa untuk selalu menghafal pelajaran. Sistem pembelajaran seperti ini tak lepas dari budaya yang sudah mengakar dalam proses pengajaran di Indonesia dimana pengembangan metode satu arah yang lebih menitik beratkan guru sebagai sumber pengetahuan utama dalam kegiatan belajar. Pola pembelajaran sejarah seperti ini membuat kreativitas belajar peserta didik menjadi terabaikan. Pengalaman-pengalaman yang telah dimiliki oleh siswa sebelumnya atau lingkungan sosialnya tidak dijadikan bahan belajar di kelas, sehingga menempatkan siswa sebagai peserta pembelajaran sejarah yang pasif. Kekurang cermatan pemilihan strategi pembelajaran akan berakibat fatal bagi pencapaian tujuan.

Melihat kenyataan yang terjadi tentu membutuhkan suatu kajian yang sangat penting ketika seorang guru akan menerapkan pembelajaran sejarah ini di sekolah dan kepada peserta didik, terlebih lagi menjawab momok yang berkembang pada para peserta didik mengatakan bahwa pembelajaran sejarah itu ialah suatu pembelajaran yang membosankan, membuat ngantuk dan malah banyak yang beranggapan tidaklah penting. Demi menghadapi persoalan seperti ini tentu profesionalisme seorang guru sangat diperlukan, bukan hanya dari faktor kemampuan guru dalam memanajemen kelas, maupun membuat variasi mengajar yang aktif dan kreatif, tetapi dari segi materi pembelajarannya sang guru perlu mengkolaborasikan 
materi yang unik dan lain dari yang biasanya contohnya seperti mengkaji dari ragam sumber informasi yang dapat memperkuat suatu pembentukkan sejarah. Hal ini bertujuan agar sumber informasi itu dapat dijadikan kajian dalam menciptakan sebuah variasi dalam materi sejarah yang akan di ajarkan nantinya.

Gottschalk (lewat Notosusanto, 2006: 43) menjelaskan terdapat dua jenis sumber informasi sejarah berdasarkan tulisan dan lisan yaitu.

1. Sumber primer yaitu kesaksian dari seorang saksi dengan mata kepala sendiri atau saksi dengan pancaindra yang lain, atau dengan alat mekanis seperti ditafon, yakni alat atau saksi mata yang hadir pada peristiwa yang diceritakannya.

2. Sumber sekunder yakni kesaksian dari pada seorang saksi yang juga mendapatkan informasi tentang kejadian berlangsung sebagai perantara dalam artian saksi tidak melihat secara langsung hal yang terjadi tersebut.

Kedua sumber ini dapat dijadikan pedoman dalam mengumpulkan informasi sejarah. Berkaitan dengan inilah seorang guru ataupun peneliti harus dapat cermat dan tepat dalam menggali informasi dari berbagai sumber yang ada guna menciptakan sebuah materi yang sesuai dengan materi sejarah kontemporer yang pernah terjadi di Indonesia khususnya kejadian lokal yang pernah ada di Kalimantan Barat untuk diambil manfaatnya dari kejadian itu menjadi pembelajaran generasi selanjutnya agar tidak mengulangi kesalahan yang sama. Dari sekian banyak materi sumber belajar yang dapat digunakan sebagai bahan kajian, konflik antar etnis di sambas tahun 1999 merupakan salah satu materi yang tersedia dan bisa digunakan sebagai materi belajar sejarah. Setiap fenomena sosial politik merupakan produk sejarah dan tidak terlepas dari latar belakang sejarahnya (history). Ini berlaku pada fenomena konflik di Kalimantan Barat. Sejak tahun 1960-an di Kalimantan Barat telah terjadi sembilan kali konflik yang cukup besar. Delapan kali di antaranya adalah konflik antara pendatang baru Madura dengan warga Dayak, dan satu kali dengan Melayu, Melayu Sambas tahun 1999. Baik masyarakat Dayak maupun Melayu Sambas memiliki pengalaman pahit yang sama dalam berhubungan dengan pendatang baru Madura.

Namun demikian, harus diakui pula bahwa banyak faktor yang dapat menjadi pemicu konflik etnis seperti di Sambas tahun 1999, diantaranya dampak dari keterusikan atas harga diri penduduk lokal, keterbelakangan ekonomi, keterasingan masyarakat lokal di daerah sendiri akibat pengaruh dan dominasi pendatang dalam bidang ekonomi, penguasaan tanah, pendatang kurang menghormati adat setempat, politik, birokrasi dan pengembangan agama. Salah satu konflik yang merupakan puncak dari semua konflik etnis di Kalimantan Barat dan berdampak sangat dalam bagi Etnis Madura sebagai warga pendatang adalah konflik etnis di Sambas tahun 1999 yang begitu menarik untuk di kaji.

Banyak sudah pihak-pihak yang mencoba menjelaskan akar permasalahan yang menimbulkan pertikaian ini, salah satunya menurut Mustofa dkk (2009:49) Konflik sosial yang terjadi di Kalimantan Barat melibatkan etnik Melayu, Dayak, dan Madura bermula dari tertangkapnya seorang pencuri di Desa Parisetia, Kecamatan Jawai, Sambas, Kalimantan Barat yang kemudian dihakimi hingga tewas pada tanggal 19 Januari 1999. Kebetulan pencuri tersebut beretnis Madura, sedangkan penduduk Parisetia beretnis Dayak dan Melayu. Entah isu apa yang beredar di masyarakat menyebabkan penduduk Desa Sarimakmur yang kebanyakan dihuni etnis Madura melakukan aksi balas dendam dengan menyerang dan merusak segala sesuatu di Desa Parisetia. Akibatnya, terjadi aksi saling balas dendam antaretnis tersebut dan menjalar ke berbagai daerah di Kalimantan Barat. Pemerintah berusaha mendamaikan konflik tersebut dengan mengajak tokoh masyarakat dari masing-masing etnis yang ada untuk membentuk Forum Komunikasi Masyarakat Kalimantan Barat. Dengan wadah tersebut segala permasalahan dicoba diselesaikan secara damai.

Terlepas dari siapa yang salah dan siapa yang benar dalam konflik antar etnis ini, 
peserta didik diharapkan dapat mengambil nilai-nilai historis agar kejadian serupa tidak terjadi atau terulang kembali di kemudian hari, sehingga tidak perlu lagi jatuh sederet korban dan penderitaan yang harus ditanggung oleh semua orang, baik yang terlibat maupun tidak. Dalam bidang pendidikan guru harus cermat menempatkan hal yang baru seperti konflik antar etnis di sambas tahun 1999 ini sebagai sumber belajar, guru perlu mengintegrasikannya ke dalam suatu materi yang terdapat pada kurikulum sejarah, agar proses penyampaian sumber belajar tersebut dapat berjalan selaras dengan tujuan pembelajaran sejarah.

Tidak terlalu sulit untuk menerapkan pembelajaran sejarah yang memanfaatkan sejarah lokal sebagai penunjang materi ajar. Sebab pada umumnya dalam proses mempelajari sejarah, peserta didik akan lebih tertarik terhadap pelajaran sejarah bila berhubungan dengan peristiwa nyata di sekitarnya. Sehingga peserta didik dapat menggambarkan suatu peristiwa masa lalu seperti dalam pembelajaran sejarah. Atas dasar pemikiran inilah maka peneliti mengangkat sebuah penelitian yang berjudul Analisis pemahaman siswa terhadap materi perkembangan masyarakat Indonesia pada masa reformasi sub bab konflik antar etnis di sambas tahun 1999 sebagai sumber belajar sejarah kelas XII IPS Sekolah Menengah Atas Negeri 08 Pontianak.

Penelitian ini bertujuan untuk mendeskripsikan tentang: (1) Pelaksanaan guru dalam menjelaskan materi perkembangan masyarakat Indonesia pada masa reformasi sub bab konflik antar etnis di sambas tahun 1999 sebagai sumber belajar sejarah kelas XII IPS SMA Negeri 08 Pontianak. (2) Strategi guru dalam menyampaikan nilai historis yang terdapat pada materi perkembangan mayarakat Indonesia pada masa reformasi sub bab konflik antar etnis di sambas tahun 1999 sebagai sumber belajar sejarah kelas XII IPS SMA Negeri 08 Pontianak. (3) Pemahaman siswa terhadap materi perkembangan masyarakat Indonesia pada masa reformasi sub bab konflik antar etnis di sambas tahun 1999 sebagai sumber belajar sejarah kelas XII IPS SMA Negeri 08 Pontianak

\section{METODE}

Penelitian ini menggunakan pendekatan deskriptif kualitatif dengan bentuk penelitian studi kasus. Nawawi (2007:78) menyatakan data Kualitatif diperoleh dari hasil observasi lapangan dan rekaman hasil wawancara yang dilakukan secara mendalam dan terbuka. Sementara data Kuantitatif diperoleh melalui dokumen-dokumen, buku, majalah, jurnal dan transkip nilainya.

Sedangkan menurut Mason dan Bramble (1998:45) descriptive reseach also conducted the broader alms sciense. In this contex, it is usually performed to develop lenopledge on which the problem and explanitions subsequest research will be based. Kalimat tersebut mengandung makna bahwa dalam penelitian ini meode yang dipilih adalah metode deskriptif, dipilihnya metode deskriptif ini karena penulis akan mendeskripsikan semua gejala yang terjadi pada saat penelitian itu dilaksanakan.

Sumber data adalah subjek utama dalam meneliti masalah di atas untuk memperoleh data-data konkrit, adapun sumber data dalam penelitian ini adalah: a). Guru bidang studi sejarah kelas XII IPS SMA Negeri 08 Pontianak, b) Siswa kelas XII IPS SMA Negeri 08 Pontianak. Untuk memperoleh data dalam penelitian ini penulis menggunakan tekhnik pengumpulan data observasi langsung, komunikasi langsung dengan alat panduan wawancara untuk memperoleh data berkenaan dengan konflik etnis di sambas tahun 1999, dan studi dokumen.

Sesuai dengan teknik data yang telah ditetapkan, maka dipelukan alat pengumpulan data yang sesuai dengan teknik dan jenis data yang hendak digunakan dalam penelitian ini yaitu berupa:

1. Panduan observasi

Adalah pencatatan data yang dilakukan oleh peneliti dengan menggunakan sebuah daftar yang memuat nama-nama reserve disertai jenis-jenis gejala yang akan diamati. Daftar itu harus disediakan sebelum observasi dilakukan. Dengan demikian tugas re- 
serve adalah memberikan tanda checklis (silang atau lingkaran dan sebagainya) apabila saat melakukan pengamatan ternyata gejala didalam daftar itu muncul, dan sebaliknya tidak memberi tanda check dalam bentuk apapun apabila gejala tersebut tidak muncul. Dengan kata lain pencatatan dilakukan untuk menyatakan muncul tidaknya suatu gejala dan jumlah pemunculannya selama observasi berlangsung.

2. Panduan Wawancara

Merupakan teknik pengumpulan data yang sering digunakan dalam penelitian kualitatif. Melaksanakan teknik wawancara berarti melakukan interaksi komunikasi atau percakapan antara pewawancara (interviewer) dan terwawancara (interviewee) dengan maksud menghimpun informasi dari interviewee. Interviewee pada penelitian kualitatif adalah informan yang dari padanya pengetahuan dan pemahaman di peroleh (Satori dan Komariah 2011: 129). Wawancara yang digunakan dalam penelitian ini adalah wawancara mendalam (in depth interviewing). Wawancara mendalam dilakukan dalam konteks observasi partisipasi. Peneliti terlibat secara intensif dengan setting penelitian terutama pada keterlibatannyadalam kehidupan informan. Arikunto (2011: 126) menyatakan interviu atau wawancara adalah dialog yang dilakukan oleh pewawancara untuk memperoleh informasi dari terwawancara. Sedangkan wawancara yang digunakan adalah dengan pola terstruktur yaitu pertanyaan yang sudah disusun dalam panduan wawancara dan responden memberikan jawabannya. Dalam hal ini, wawancara atau interviu dilakukan kepada informan dengan menggunakan alat pengumpul data yang telah dirumuskan dalam bentuk panduan wawancara.

\section{Dokumentasi}

Merupakan suatu teknik pengumpulan data dengan menghimpun dan menganalisis dokumen-dokumen, baik dokumen tertulis, gambar maupun elektronik. Analisis dokumen dilakukan untuk mengumpulkan data yang bersumber dari arsip dan dokumen baik, yang memiliki hubungan dalam penelitian tersebut. Menurut Arikunto (2011:
132), teknik dokumentasi yaitu mencari data mengenai hal atau variable yang berupa catatan, transkip, buku, surat kabar, majalah, prasasti, notulen rapat, agenda dan sebagainya. Dengan demikian dapat di katakan dokumen merupakan sumber informasi yang bukan manusia. Nasution (lewat Satori \& Komariah, 2011: 146) menyebutkan bahwa ada pula sumber non manusia (non human resources), di antaranya dokumen, foto dan bahan statistik. Secara harfaiah juga dapat dikatakan bahwa dokumen itu ialah suatu catatan kejadian yang sudah lampau.

Teknik cuplikan atau sampling yang digunakan dalam penelitian ini adalah purposive sampling, yaitu teknik memilih sampel yang termasuk nonprobabilitas yang memilih sampel dengan dasar bertujuan. Teknik ini juga populer disebut sebagai purposive sampling, karena untuk menentukan seseorang menjadi sampel atau tidak didasarkan pada tujuan tertentu, misalnya dengan pertimbangan profesional yang dimiliki oleh si peneliti dalam usahanya memperoleh informasi yang relevan dengan tujuan penelitian (Darmadi 2011:64). Dalam penelitian ini akan di pilih seorang guru bidang studi sejarah dan siswa kelas XII IPS yang akan dijadikan sasaran penelitian, terebih dahulu dipilih berdasarkan karakteristik tertentu (criterion-based selection) sesuai dengan kebutuhan dan kemantapan peneliti dalam perolehan data. Kriteria yang digunakan dalam menentukan informan adalah guru bidang studi sejarah dan siswa kelas XII IPS SMA Negeri 08 Pontianak.

Untuk memastikan kedalaman dan kemantapan serta kebenaranya data yang diperoleh, peneliti harus bisa memilih dan menentukan cara yang tepat untuk mengembangkan validasi datanya. Validasi merupakan derajat ketepatan antara data yang terjadi pada objek penelitian dengan data yang dapat dilaporkan oleh peneliti (Satori dan Komariah, 2011:162). Validasi data merupakan faktor yang penting dalam sebuah penelitian, karena sebelum data dianalisis terlebih dahulu harus mengalami pemeriksaan untuk menentukan tingkat kepercayaan data yang diperoleh. Adanya tingkat kepercayaan yang 
tinggi, menjadikan data yang digunakan semakin baik karena telah teruji kebenarannya dan merupakan jaminan bagi kemantapan simpulan dan tafsir makna sebagai hasil penelitian (Sutopo, 2006:92). Untuk menguji data dalam penelitian ini digunakan teknik trianggulasi. Teknik trianggulasi adalah teknik pemeriksaan validasi data yang menggunakan pandangan multiperspektif, sehingga untuk menarik simpulan yang mantap diperlukan tidak hanya dari satu cara pandang. Patton (lewat Sutopo, 2006:92). Menyatakan ada 4 macam teknik trianggulasi, yakni: 1) trianggulasi data, 2) trianggulasi peneliti, 3) trianggulasi metodelogis, 4) trianggulasi teoritis. Namun dalam penelitian ini hanya digunakan trianggulasi data dan trianggulasi metode.

Melakukan analisis adalah pekerjaan yang sulit, memerlukan kerja keras. Analisis merupakan daya kreatif serta keampuan intelektual yang tinggi. Tidak ada cara tertentu yang dapat diikuti untuk mengadakan analisis, sehingga setiap peneliti harus mencari sendiri metode yang dirasakan cocok dengan sifat penelitinya. Nasution (lewat Sugiyono 2010:334) menyatakan bahan yang sama bisa di klasifikasikan lain oleh peneliti yang berbeda. Dari definisi di atas dapat di tarik kesimpulan bahwa Penelitian kualitatif menekankan pada analisis secara induktif, sehingga data yang dikumpulkan bukan untuk mendukung atau menolak hipotesis yang diajukan seelum penelitian dilakukan, tetapi data dikumpulkan dan dikelompokkan dalam pola, tema atau kategori untuk selanjutnya ditarik suatu kesimpulan sementara dengan cermat dan hati-hati.

Selanjutnya kesimpulan sementara dirumuskan secepat mungkin menjadi kesimpulan-kesimpulan yang kokoh, kuat dan mengandung makna sebelum data tersebut tertumpuk. Kesimpulan tersebut bertujuan untuk menjawab pertanyaan-pertanyaan penelitian serta dapat dijadikan sebagai temuan-temuan penelitian yang bermanfaat. Teknik analisis data adalah upaya yang dilakukan dengan jalan bekerja dengan data, mengorganisasikan data, memilah-milahnya menjadi satuan yang dapat dikelola, mensin- tesiskannya, mencari dan menemukan apa yang penting dan apa yang dipelajari dan memutuskan apa yang dapat diceritakan. Sebelum dilakukan analisis, semua data yang telah terkumpul, baik data primer maupun data sekunder diidetifikasi dan diklasifikasikan sesuai dengan permasalahan yang diajukan. Selanjutnya data diklasifikasi, dianalisis dengan mengaplikasikan teori - teori yang telah di tetapkan. Adapun analisis yang digunakan dalam penelitian ini adalah analisis deskriftif kualitatif dan interpretatif. Analisis seperti ini meupakan bagian dari prosedur penelitian kualitatif yang lebih menekankan pada upaya memahami makna atau menafsirkan realitas empirik dari obyek penelitian (Singarimbun, 2005:143). Milles dan Huberman (lewat Sugiyono 2010:337), mengemukakan bahwa aktivitas dalam analisis data kualitatif dilakukan secara terus menerus sampai tuntas, sehingga datanya sudah jenuh. Aktivitas dalam analisis data, yaitu reduksi data, penyajian data, menarik kesimpulan dan verifikasi.

1. Reduksi data

Reduksi data dalam penelitian berarti merangkum, memilah hal-hal yang pokok, memfokuskan pada hal-hal yang penting, dicari tema dan polanya dan membuang yang tidak perlu (Sugiyono 2010:338). Reduksi data adalah proses pemilahan, pemusatan perhatian pada penyederhanaan, pengabstrakan dan transformasi data kasar yang muncul dari catatan - catatan tertulis di lapangan, yang berlangsung terus menerus selama penelitian berlangsung.

Dalam proses ini, peneliti merangkum dan memilih data yang di anggap pokok serta di fokuskan sesuai dengan fokus penelitian. Dalam mereduksi data, semua data lapangan ditulis sekaligus dianalisis, direduksi, dirangkum, dipilih hal-hal yang penting, dicari tema dan polanya, sehingga disusun secara sistematis dan lebih mudah dikendalikan. Setelah direduksi diharapkan data akan memberikan gambaran yang lebih jelas, dan mempermudah peneliti untuk melakukan pengumpulan data selanjutnya dan mencarinya bila diperlukan.

2. Penyajian data 
Penyajian data adalah merangkai dan menyusun informasi yang memberi kemungkinan adanya penyederhanaan informasi yang kompleks dan mudah dipahami. Penyajian data menggunakan bentuk teks naratif yang dilengkapi dengan jaringan kerja sehingga semua informasi yang disusun mudah dilihat dan dimengerti. Dalam hal ini Milles dan Huberman (lewat Sugiyono 2010:341) menyatakan The most frequent from of display data for qualitative research data in the past has been narrative tex.

Penyajian data (display data) maksudnya menyajikan sekumpulan informasi yang tersusun, yang memungkinkan adanya penarikan kesimpulan dan pengambilan tindakan. Setelah data direduksi, maka langkah selanjutnya adalah mendisplay data. Data yang di sajikan dalam penelitian adalah data yang sebelumnya sudah dianalisa, tetapi analisis yang dilakukan masih berupa catatan untuk kepentingan peneliti sebelum disusun dalam bentuk laporan. Penyajian data dirancang untuk merakit informasi yang tersusun dalam bentuk yang dapat diakses secara langsung, bentuk yang praktis, sehingga peneliti dapat melihat apa yang terjadi dan lebih mudah menarik kesimpulan.

3. Menarik kesimpulan dan verifikasi

Sejak memulai pengumpulan data, analisis kualitatif sudah dilakukan yaitu dengan kegiatan mencari arti, pola-pola, penjelasan, konfigurasi-konfigurasi yang mungkin, alur sebab akibat dan proposisi. Selain itu penarikan kesimpulan pada hakikatnya sebagian dari satu kegiatan dari konfigurasi yang utuh. Makna-makna yang muncul dari data harus diuji kebenarannya, kekokohannya dan kecocokkannya yang sekaligus jadi validasinya. Pada langkah ini, peneliti menyusun secara sistematis data yang sudah disajikan, selanjutnya berusaha untuk menarik kesimpulan dan data-data tersebut sesuai dengan fokus penelitian.

Kesimpulan awal yang dikemukakan masih bersifat sementara dan akan berubah bila tidak ditemukan bukti-bukti yang kuat yang mendukung pada tahap pengumpulan data berikutnya. Tetapi apabila didukung oleh bukti-bukti yang valid dan konsisten saat pengumpulan data kembali, maka kesimpulan yang dikemukakan merupakan kesimpulan yang kredibel. Dengan demikian kesimpulan penelitian kualitatif mungkin dapat menjawab fokus penelitian yang dibuat sejak awal, tetapi mungkin juga tidak karena penelitian kualitatif bersifat lentur (fleksibel) masalah atau fokus penelitiannya bisa saja berubah dan berkembang setelah peneliti berada di lapangan.

Teknik analisa data yang digunakan adalah metode interaktif, yaitu antara proses pengumpulan data, reduksi data (penyusunan data dalam pola, kategori, pokok permasalahan tertentu), penyajian data (penyusun data dalam bentuk matrik, grafik, jaringan, bagan tertentu) dan pengambilan kesimpulan, tidak dipandang sebagai kegiatan yang berlangsung secara linier, namun merupakan siklus interaktif.

\section{HASIL DAN PEMBAHASAN}

Persiapan guru dalam menjelaskan materi perkembangan masyarakat Indonesia masa reformasi sub-bab konflik antaretnis di Sambas tahun 1999.

Pembelajaran sejarah di sekolah berlangsung selama 2 jam mata pelajaran dalam seminggu. Dalam penelitian ini materi perkembangan masyarakat Indonesia pada masa reformasi dilaksanakan pada semester ganjil. Sehubung dengan hal ini, penyampaian materi oleh guru sejarah sudah memberikan pengajaran yang optimal. Bentuk optimal tersebut terlihat dari upaya guru dalam menyampaikan materi yang tidak hanya mengandalkan metode ceramah satu arah, tetapi juga menggunakan seperangkat media seperti proyektor untuk menampilkan film dokumenter, slide-slide photo serta bahan ajar berbentuk power point yang berkaitan dengan materi yang akan disampaikan. Hal ini bisa akan lebih mudah dicerna dan dipahami oleh siswa.

Kurikulum, materi, metode dan pendekatan pembelajaran pendidikan sejarah di sekolah harus mampu memberikan pengalaman kepada siswa untuk bisa menarik pelajaran 
dari peristiwa sejarah, melihat relevansinya dengan peristiwa atau kehidupan masa kini, dan dikembangankan untuk kehidupan masa datang. Menghubungkan satu peristiwa dengan peristiwa lainnya secara logis. Penggunaan metode yang memanfaatkan alat elektronik seperti proyektor dalam pembelajaran sejarah sepertinya belum banyak digunakan oleh Guru dalam mengajar sejarah, dalam proses pembelajaran, Guru lebih cenderung menggunakan ceramah dan mencatat materi pembelajaran hingga berakhirnya waktu pelajaran dan hal ini masih saja mendominasi.

Metode ceramah memang dibutuhkan dalam mentransformasikan pengetahuan sejarah. Begitu juga dengan kebiasaan mencatat bahan pelajaran yang di anggap penting sebagai referensi siswa untuk menghadapi tes, ulangan dan sebagainya, tetapi hal ini akan menimbulkan sikap bosan dan jenuh pada siswa. Apalagi guru kurang mampu mengelola kelas, maka kreativitas guru dalam mengolah bahan ajar agar dikemas menjadi lebih menarik sangat di perlukan hal ini supaya dapat memicu semangat siswa untuk belajar pelajaran sejarah.

\section{Pelaksanaan guru dalam menyampaikan nilai historis yang terdapat pada materi perkembangan mayarakat Indonesia pada masa reformasi sub bab konflik an- tar etnis di Sambas tahun 1999.}

Strategi pembelajaran merupakan suatu metode pendidikan untuk menciptakan suana belajar yang aktif dan menarik. Strategi pembelajaran adalah keseluruhan usaha Guru termasuk perencanaan, cara dan taktik yang digunakan untuk mencapai tujuan belajar yang telah ditentukan sebelumnya. Strategi Guru dalam menyampaikan nilai historis yang terdapat pada materi perkembangan masyrakat Indonesia pada masa reformasi sub bab konflik antar etnis di Sambas tahun 1999 yaitu dengan menggunakan video dokumenter dan beberapa slide photo yang menggambarkan peristiwa tersebut serta diberi beberapa penjelasan yang berkaitan dengan materi yang disampaikan. Penyampaian materi ini diberikan kepada siswa agar minat saling menghargai dan menjunjung tinggi budaya masing-masing suku di Indonesia terutama di Kalimantan Barat, dapat tumbuh dalam diri siswa. Saling menjaga dan saling mengingatkan akan keindahan beragam budaya dan bahasa demi menyongsong kerukunan antar suku di masa yang akan datang.

Strategi Guru dalam menyampaikan materi tersebut adalah dengan memberikan pengetahuan mengenai peristiwa di daerah sekitar siswa agar siswa lebih termotivasi karena mendapat pengetahuan baru dan dapat digunakan untuk kehidupannya dengan mengambil nilai-nilai dari peristiwa terdahulu. Untuk memberikan wawasan kesejarahan lokal yang diintegrasikan kedalam sejarah nasional berupa sejarah kontemporer, maka langkahnya bisa mengambil materi sejarah lokal ini utuk dijadikan sumber belajar. Dalam hal ini dari materi perkembangan masyarakat Indonesia pada masa Reformasi sub-bab konflik antaretnis di Sambas tahun 1999 sebagai sumber belajar sejarah di kelas XII IPS Sekolah Menengah Atas Negeri 8 Pontianak. Hal ini sesuai pendapat Zuldafrial (2011: 227) tentang pertimbangan yang dapat digunakan untuk megambil materi tertentu dari lingkungan untuk digunakan dalam pembelajaran yaitu: (1) tujuan pembelajaran yang hendak dicapai. Materi yang diambil hendaknya berada dalam ruang lingkup tujuan yang dimaksud, (2) unsur-unsur lima: materi yang diambil dapat dimuati unsur-unsur lima yaitu iman dan takwa artinya materi dapat mengembangkan kreativitas belajar siswa, individu artinya materi dapat mengembangkan potensi dan kemampuan siswa, dan interaksi yaitu materi dapat menciptakan interaksi belajar yang dinamis diantara peserta didik, (3) perkembangan dan kemampuan peserta didik. Materi yang diambil sesuai dengan tingkat perkembangan dan kemampuan yang telah dimiliki peserta didik. (4) kurikulum: materi yang diambil berada di dalam wilayah kurikulum program pendidikan tertentu. (5) waktu pembelajaran yang tersedia: materi yang diambil terutama dari sisi keleluasaan dan kedalamannya, sesuai dengan banyaknya waktu yang dapat digunakan untuk terselenggaranya proses pem- 
belajaran.

Dengan adanya penyatuan antara materi sejarah lokal dengan sejarah nasional akan memberikan pengetahuan dan cerita tentang sejarah peristiwa konlik antar etnis di sambas tahun 1999 beserta data-data yang konkrit yang bisa dilihat hingga sekarang. Dengan demikian siswa terlihat lebih aktif dalam mendengarkan penjelasan dari Guru tersebut.

\section{Pemahaman siswa terhadap materi perkembangan masyarakat Indonesia pada masa reformasi sub bab konflik an- tar etnis di Sambas tahun 1999.}

Pemahaman sejarah diperlukan untuk menentukan alternatif masa yang akan datang yang berakar dalam realitas sejarah. Nilai utama belajar sejarah adalah membantu siswa mengembangkan wawasan dan pemahaman tentang sejarah. Pemahaman nilai guna sejarah adalah untuk memahami diri kita dan masalah-masalah kemanusiaan pada masa kini dan mendatang sebagai peranan pendidikan sosial sejarah.

Pemahaman sejarah sebagai aspek kesadaran sejarah dapat tumbuh dalam pembelajaran menyentuh ranah siswa, yaitu ranah kognitif. Siswa yang memiliki pemahaman sejarah dapat terlihat dari kapasitas kesejarahan yang dimilikinya sebagai hasil pembelajaran. Aspek efektif dan psikomotor terlihat dalam pembelajaran tanpa paksaan atau tekanan dari luar atau guru.

Pemahaman siswa terhadap sejarah lokal konflik etnis di sambas tahun 1999 dilihat dari keterlibatan siswa dalam pembelajaran sejarah yang terlihat aktif pada saat guru menyampaikan materi. Siswa yang pernah mendengar cerita tersebut atau berasal dari daerah sambas. Menceritakan pengetahuan yang dimilikinya dan berbagi cerita dengan teman lainnya yang belum mengetahui sejarah tersebut. Siswa juga selalu menjawab pertanyaan yang diberikan guru serta menanyakan berbagai hal yang kurang siswa pahami. Materi ini membuat siswa aktif dan kreatif dalam pembelajaran dan terciptanya suasana belajar yang kondusif. Siswa yang tumbuh minat belajarnya akan terlihat aktif dalam pembelajaran sejarah seperti tanya jawab, memecahkan masalah, diskusi, menjelaskan, menganalisis dan mengerjakan tugas-tugas yang diberikan oleh guru.

\section{SIMPULAN}

Berdasarkan analisis data dan hasil observasi serta hasil wawancara, secara umum dapat disimpulkan bahwa pemahaman siswa terhadap materi perkembangan masyarakat Indonesia pada masa reformasi sub-bab konflik antaretnis di Sambas tahun 1999 sebagai sumber belajar sejarah kelas XII IPS SMA Negeri 08 Pontianak, sudah cukup baik. Secara khusus dapat di tarik kesimpulan sebagai berikut.

Persiapan guru dalam menjelaskan materi yaitu menggunakan media proyektor dengan menampilkan power point dan di selingi film dokumenter. Materi yang di sampaikan juga sudah mengikuti Silabus dan RPP yang sudah ada. Pelaksanaan guru dalam menyampaikan nilai historis yang terdapat pada materi yaitu dengan mengajak siswa untuk menyaksikan film dokumenter yang mengisahkan tentang peristiwa konflik tersebut setelah menonton guru menjelaskan dampak buruk dari peristiwa tersebut dan mengajak siswa untuk bisa mengambil hikmahnya dengan saling menghormati dan menjaga perbedaan yang ada. Sehingga peristiwa serupa tidak terulang kembali. Pemahaman siswa terhadap materi yang diajarkan cukup baik, nampak pada siswa terlihat aktif dalam pembelajaran sejarah tanpa ada paksaan atau tekanan dari guru. Materi ini menjadikan siswa untuk berfikir secara kronologis dan memiliki pengetahuan peristiwa masa lampau menjadikan siswa siap untuk menghadapi masa depan.

\section{UCAPAN TERIMA KASIH}

Dalam kesempatan ini penulis mengucapkan terima kasih kepada berbagai pihak yang telah membantu dalam pelaksanaan penelitian ini. Penulis juga mengucapkan terima kasih kepada dewan redaksi Jurnal Socia atas kesempatan yang diberikan sehingga paper ini dapat diterbitkan pada Jurnal Socia edisi September 2015. 


\section{DAFTAR PUSTAKA}

Arikunto, S. (2011). Metodelogi Penelitian Ilmu Sosial. Jakarta : Rineka Cipta.

Darmadi, H. 2011. Metode Penelitian Pendidikan. Bandung: Alfabeta.

Mason J. E. dan Bramble, W.J. (1998). Kualitatif Research for Education. London: Library of Congress Cataloging in Publication Data.

Nawawi, H. (2007). Metode Penelitian Bidang Sosial. Yogyakarta: Gajah Mada University Press.

Notosusanto. 2006.

Satori, D. dan Komariah. (2011). Metodelogi Penelitian Kualitatif. Bandung : Alfabeta.
Singarimbun. (2005). Pedoman Pengajaran Mikro dan Praktek Lapangan. Pontianak: Romeo Grafika.

Mustofa., Suryandari., Mulyati, T. 2009. Sejarah untuk SMA/MA Kelas XII Program IPS. Jakarta : Departemen Pendidikan Nasional.

Sugiyono. 2010. Metodelogi Penelitian Pendidikan. Bandung : Alfabeta.

Sutopo, H.B. 2006. Metode Penelitian Kualitatif. Surakarta : Universitas Sebelas Maret.

Zuldafrial. 2011. Strategi Belajar Mengajar. Pontianak STAIN : Pontianak Press. 